Sedgley, M., J. Harbard, R. M. M. Smith, R. WickNESWARI and A. R. GRIFFIN (1992): Reproductive biology and interspecific hybridization of Acacia mangium and Acacia auriculiformis A. Cunn. ex Benth (Leguminosae: Mimosoideae). Australian Journal of Botany 40: 37-48.

ShIRAISHI, S and A. WATANABE (1995): Identification of chloroplast genome between Pinus densiflora Sieb. et Zucc and $P$. thunbergii Parl. based on polymorphisms in $r b c \mathrm{~L}$ gene. Journal of Japanese Forest Society 77: 429-436. (in Japanese with English abstracts)

TuRnBulL, J. W. (1986): Multipurpose Australia trees and shrubs: lesser known species for fuel wood and agroforestry. ACIAR Monograph No. 1, pp316.

Vallone, P. M., R. S. Just, M. D. Coble, J. M. Butler and T. J. PARSONS (2004): A multiplex allele-specific primer extension assay for forensically informative SNPs distributed throughout the mitochondrial genome. Int. J. Legal Med 118: 147-157.

VAllone, P. M and J. M. ButLER (2004): Y-SNP typing of U.S. African American and Caucasian samples using allele-specific hybridization and primer extension. Journal of Forensic Sciences 49: 723-732.

Vallone, P. M, A. E. Decker, M. D. Coble and J. M. ButLER (2006): The evaluation of an autosomal SNP 12-plex assay. International Congress Series 1288: 61-63.
VARshney, R. K., U. Beier, E. K. KhlestKina, R. Kota, V. Korzun, A. Graner and A. Borner (2007): Single nucleotide polymorphisms in rye (Secale cereale L.): discovery, frequency, and applications for genome mapping and diversity studies. Theoretical Applied Genetics 114: 1105-1116.

Vignal, A., D. Milan, M. Sancristobal and A. EgGen (2002): A review on SNP and other types of molecular markers and their use in animal genetics. Genetics Selection Evolution 34: 275-305.

WenG, C., T. L. KubisiaK and M. STINe (1998): SCAR markers in a longleaf pine $\mathrm{x}$ slash pine $\mathrm{F} 1$ family. Forest Genetics 5: 239-247.

Werner, F. A. O., G. Durstewitz, F. A. Habermann, G. Thaller, W. Kramer, S. Kollers, J. Buitkamp, M. Georges, G. Brem, J. Mosner and R. Fries (2004): Detection and characterization of SNPs useful for identity control and parentage testing in major European dairy breeds. Animal Genetics 35: 44-49.

William, J. G., A. R. Kubelik, K. J. LivaK, J. A. RAFAlski and S. V. TINGEY (1990): DNA polymorphisms amplified by arbitrary primers are useful as genetic markers. Nucleic Acids Research 18: 6531-6535.

Yoon, M. S., Q. J. Song, I. Y. ChoI, J. E. Specht, D. L. Hyten and P. B. CRegan (2007): BARCSoySNP23: a panel of 23 selected SNPs for soybean cultivar identification. Theoretical Applied Genetics 114: 885-899.

\title{
Short Note: Seven Genomic SSRs Revealed in Eucalyptus by Re-sequencing of DNA Sequences from GenBank
}

\author{
By X. $\mathrm{HE}^{1,2)}, \mathrm{F} . \mathrm{LI}^{1)}, \mathrm{J} . \mathrm{SHI}^{2)}$ and S. GAN ${ }^{1, *}$ ) \\ (Received $28^{\text {th }}$ January 2010)
}

\begin{abstract}
Seven genomic SSR markers of Eucalyptus were developed from DNA sequences of $E$. grandis deposited in GenBank. Their repeat motifs were revealed by resequencing with an individual tree of $E$. urophylla or E. tereticornis, and five out of the seven markers turned out to be heterozygous within the specific tree sequenced. The sequence identity ranged from $75.06 \%$ to $96.66 \%$, with an average of $87.31 \%$. These markers

\footnotetext{
1) Research Institute of Tropical Forestry and National Key Laboratory of Forest Tree Genetics and Breeding, Chinese Academy of Forestry, Longdong, Guangzhou 510520, People's Republic of China.

2) The Key Laboratory of Forest Genetics and Biotechnology of Ministry of Education, Nanjing Forestry University, 159 Longpan Road, Nanjing 210037, People's Republic of China.

*) Corresponding author: SimING GAN. Tel: +86 2087032402 , Fax: +86 20 87031622. E-mail: Siming.Gan@ritf.ac.cn.
}

could be valuable in genetics studies in Eucalyptus. This report demonstrates the advantages of re-sequencing in developing SSR markers from publicly accessible databases.

Key words: Simple sequence repeats (SSRs), microsatellites, molecular markers, Eucalyptus, re-sequencing.

Simple sequence repeats (SSRs), as known as microsatellites, are useful markers for a wide spectrum of biological applications (POWELL et al., 1996; GUPTA and VARSHNEY, 2000). To date, a large number of SSR markers have been produced for a number of plant species, e.g. more than 5000 SSRs available for sorghum (Sorghum bicolor) (YonEMARU et al., 2009). In the woody genus Eucalyptus (family Myrtaceae), however, only 367 genomic SSRs (as reviewed in BRONDANI et al., 2006) and 68 EST-SSRs (FARIA et al., 2010, 2011; ZHOU et al., 
2010) have been reported, and the SSR marker resources are still limited. Thus, it may be necessary to develop more eucalypt SSR markers, especially from publicly accessible genomic databases, such as GenBank.

In this study we explore the possibility of developing SSR markers in Eucalyptus from publicly available DNA sequences. A total of $167 E$. grandis DNA fragments with three definitions (Table 1) were downloaded from GenBank (http://www.ncbi.nlm.nih.gov/ nucleotide/), 47 of which were identified to contain tandem repeats using a Perl script Microsatellite Identification Tool (MISA, http://pgrc.ipk-gatersleben.de/misa), in which a minimum of $12,12,12,15$ and 18 bases were set for di-, tri-, tetra-, penta- and hexa-nucleotide repeats, respectively. After excluding the fragments with too short or inappropriate flanking sequences, thirtythree primer pairs were designed using Primer 3 (ROzEN and SKALETSKY, 2000) and synthesized by Invitrogen Co. (Shanghai, China).

PCR was conducted using the maternal E. urophylla $\left(\mathrm{P}_{1}, \mathrm{UX}-30\right)$ and paternal $E$. tereticornis $\left(\mathrm{P}_{2}, \mathrm{~T} 4305\right)$ parents of a mapping population (GAN et al., 2003). PCRs of $10 \mu \mathrm{L}$ consisted of $1.0 \mu \mathrm{L} 10 \mathrm{x}$ buffer $(100 \mathrm{mM}$ Tris-HCl pH9.0, $100 \mathrm{mM} \mathrm{KCl}, 80 \mathrm{mM}\left(\mathrm{NH}_{4}\right)_{2} \mathrm{SO}_{4}$ and $0.5 \% \mathrm{NP}$ -

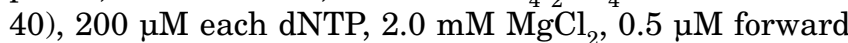
primer, $0.5 \mu \mathrm{M}$ reverse primer, $1 \mathrm{U}$ Taq DNA polymerase (Biocolors Technology Co., Shanghai, China) and about 5 ng DNA template. The PCRs were done in 96well plates on a DNA Engine thermal cycler (Bio-Rad, Hercules, CA, USA) using the following program: $94^{\circ} \mathrm{C}$ for $4 \mathrm{~min}$; 35 cycles of $94^{\circ} \mathrm{C}$ for $30 \mathrm{~s}, 56^{\circ} \mathrm{C}$ for $30 \mathrm{~s}$, and

Table 1. - Seven genomic SSR markers developed in Eucalyptus. $\mathrm{P}_{1}$, E. urophylla; $\mathrm{P}_{2}$, E. tereticornis.

\begin{tabular}{|c|c|c|c|c|c|c|c|}
\hline Marker & $\begin{array}{c}\text { GenBank } \\
\text { accession } \\
\text { (ProbeDB ID) }\end{array}$ & $\begin{array}{l}\text { Repeat motif revealed in } \\
\text { re-sequencing }\end{array}$ & $\begin{array}{c}\text { Repeat motif in } \\
\text { original DNA } \\
\text { sequences }\end{array}$ & $\begin{array}{l}\text { Forward primer }\left(5^{\prime}-3^{\prime}\right) \\
\text { Reverse primer }\left(5^{\prime}-3^{\prime}\right)\end{array}$ & $\begin{array}{l}\text { Expected } \\
\text { length } \\
\text { (bp) }\end{array}$ & $\begin{array}{c}\text { Re-sequenced } \\
\text { length } \\
\text { (bp) }\end{array}$ & Identity \\
\hline EUCgSSR01 & $\begin{array}{l}\mathrm{BD} 272940^{\mathrm{a}} \\
(10703611)\end{array}$ & $\mathrm{P}_{2}:(\mathrm{GA})_{21 / 25}$ & $(\mathrm{GA})_{22}$ & $\begin{array}{l}\text { F: ACGCCACATTGGACCTTT } \\
\text { R:CCGAGCTGCTGGATAACG }\end{array}$ & 333 & $294 / 302$ & $\begin{array}{l}76.82 \% \\
(232 / 302)\end{array}$ \\
\hline EUCgSSR05 & $\begin{array}{l}\mathrm{BD} 262196^{\mathrm{b}} \\
(10703612)\end{array}$ & $\mathrm{P}_{1}:(\mathrm{CT})_{12: 13}$ & $(\mathrm{CT})_{14}$ & $\begin{array}{l}\text { F: ACAAAGTGAAACCCAAGC } \\
\text { R:GGAAGAGCAGGACCAGTA }\end{array}$ & 462 & $431 / 433$ & $\begin{array}{c}75.06 \% \\
(325 / 433)\end{array}$ \\
\hline EUCgSSR 20 & $\begin{array}{l}\text { DD458136 } \\
(10703613)\end{array}$ & $P_{1}:(A G)_{n}+(G A G C G A)_{3}$ & $(\mathrm{AG})_{6}+(\mathrm{GAGCGA})_{3}$ & $\begin{array}{l}\text { F: ACTGAAGTGACTGACTGATG } \\
\text { R:GTCGGAGTCGTGGCGTAT }\end{array}$ & 334 & 299 & $\begin{array}{c}96.66 \% \\
(289 / 299)\end{array}$ \\
\hline EUCgSSR 21 & $\begin{array}{l}\text { DD458137 } \\
(10703614)\end{array}$ & $\mathrm{P}_{1}:(\mathrm{TCT})_{\mathbf{n}}(\mathrm{TCG})_{9}$ & $(\mathrm{TCT})_{6}(\mathrm{TCG})_{9}$ & $\begin{array}{l}\text { F: TCGCCTCGTTCGTCATCTT } \\
\text { R:CGCTGCTTGTTCCACCATT }\end{array}$ & 223 & 192 & $\begin{array}{c}96.35 \% \\
(185 / 192)\end{array}$ \\
\hline EUCgSSR23 & $\begin{array}{l}\text { DD458141 } \\
(10703615)\end{array}$ & $\mathrm{P}_{1}:(\mathrm{CT})_{8: 9}$ & $(\mathrm{CT})_{9}$ & $\begin{array}{l}\text { F:CCCCGTATCACTCATCTCC } \\
\text { R:TTTAGCCGAGTCCCAGAA }\end{array}$ & 264 & $228 / 230$ & $\begin{array}{l}80.43 \% \\
(185 / 230)\end{array}$ \\
\hline EUCgSSR 25 & $\begin{array}{l}\mathrm{BD} 262179^{\mathrm{b}} \\
(10703616)\end{array}$ & $P_{1}:(G A)_{13 / 14}$ & $(\mathrm{GA})_{18}$ & $\begin{array}{l}\text { F: ATCACATCCATCCAGCCTCCAC } \\
\text { R:CCGCCATCACCTTCCAAGAC }\end{array}$ & 232 & $183 / 185$ & $\begin{array}{c}92.97 \% \\
(172 / 185)\end{array}$ \\
\hline EUCgSSR26 & $\begin{array}{l}\mathrm{BD} 262120^{\mathrm{b}} \\
(10703617)\end{array}$ & $\mathrm{P}_{2}:(\mathrm{GA})_{>4 / 5}$ & $(\mathrm{GA})_{17}$ & $\begin{array}{l}\text { F: AAAGGTCAGATGTCATCCCACG } \\
\text { R:ACCAACCCTCCCGCAAAA }\end{array}$ & 153 & $110 / 112$ & $\begin{array}{c}92.86 \% \\
(104 / 112)\end{array}$ \\
\hline
\end{tabular}

a Definition: Materials and methods for the modification of isoprenoid content, compostition and metabolism.

${ }^{\mathrm{b}}$ Definition: Composition and methods for the modification of gene expression.

c Definition: Compositions and methods for regulating polysaccharides of a plant cell.

d The symbols "n" and ">" denote no and partial repeats, respectively, visible in the re-sequencing profile as the SSR motifs were included in (e.g. four bases for EUCgSSR21) or very close to (e.g. three bases for EUCgSSR20 and zero base for EUCgSSR26) the end of the forward sequencing primer site.

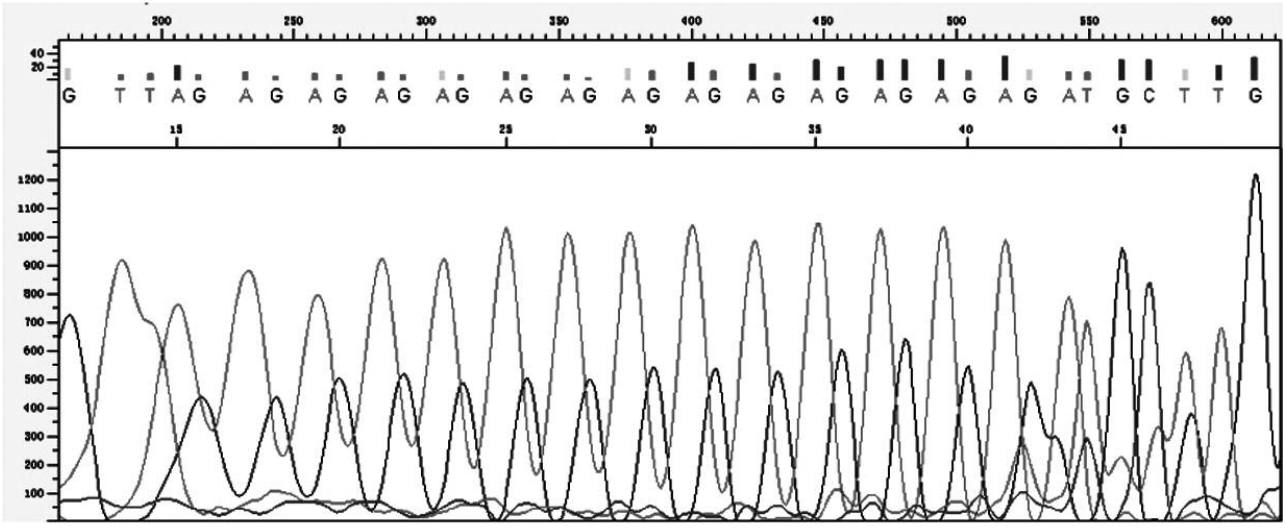

Higher base: GTTAGAGAGAGAGAGAGAGAGAGAGAGAGAGATGCTTG Lower base: GTTAGAGAGAGAGAGAGAGAGAGAGAGAGATGCTTG

Figure 1. - Partial re-sequencing profile of marker EUCgSSR25 with $\mathrm{P}_{1}$. The higher and lower bases correspond to the larger (185 bp) and shorter (183 bp) alleles sequenced, respectively. The underlined letters show the identical bases downstream of the SSR motifs. 
$72{ }^{\circ} \mathrm{C}$ for $1 \mathrm{~min}$; and a final extension at $72{ }^{\circ} \mathrm{C}$ for 10 min. The PCR products were checked through electrophoresis in 1.5\% agarose gels containing 1:20 GoldView (SBS Genetech Co., Beijing, China) and photographed with Photoprint 215SD (Vilber Lourmat Co., Marne la Vallée, France).

PCR products of either $\mathrm{P}_{1}$ or $\mathrm{P}_{2}$ were sequenced using BigDye Terminator Version 3.1 (BDT3.1) and an ABI 3130xl Genetic Analyzer (Applied Biosystems, Foster City, CA) according to the manufacturer's instructions except that $0.5 \mu \mathrm{L}$ of BDT3.1 was used in the sequencing reaction instead of the standard $8.0 \mu \mathrm{L}$ (ZHANG et al., 2009). Seven SSRs were verified in re-sequencing, including five that were heterozygous within the specific tree that was sequenced (Table 1). Figure 1 shows a partial re-sequencing profile of marker EUCgSSR25 with $\mathrm{P}_{1}$.

The nucleotide sequences generated in re-sequencing were aligned with the target sequences using DNAMAN version 5.2.2 (Lynnon Biosoft, Quebec, Canada). The identity ranged from $75.06 \%$ in EUCgSSR05 to $96.66 \%$ in EUCgSSR20 (Table 1), with an average of $87.31 \%$. BLASTN searches within the GenBank database (http://blast.ncbi.nlm.nih.gov/Blast.cgi) revealed that EUCgSSR01 was highly similar to an EST-SSR Embra1868 (FARIA et al., 2010) while there were no similar markers for the rest six SSRs. The seven SSRs were deposited in ProbeDB of GenBank with IDs 1070361110703617 (Table 1; http://www.ncbi.nlm.nih.gov/sites/ entrez?db=probe).

The set of seven SSR markers reported here will make a valuable addition to the growing collection of SSR markers for genetic studies in Eucalyptus. This report demonstrates several advantages of re-sequencing in developing SSR markers from publicly accessible databases: (i) relatively low cost and high efficiency; (ii) direct identification of heterozygous markers, which may be highly variable; and (iii) potential to identify other variations within the flanking sequences, e.g. single nucleotide polymorphism (SNP) and insertion/deletion (indel).

\section{Acknowledgements}

This work was supported by the National Natural Science Foundation of China (No. 31070592), the Guangdong Natural Science Foundation (No. 10151052001000000), National Program of High Technology Development of China (No. 2011AA100202) and the Ministry of Finance of China through a specific program for national non-profit scientific institutions (Nos. RITF2007-6 and RITF2008-4). We thank YU WANG for her technical assistance.

\section{References}

Brondani, R. P. V., E. R. Williams, C. Brondani and D. Grattapaglia (2006): A microsatellite-based consensus linkage map for species of Eucalyptus and a novel set of 230 microsatellite markers for the genus. BMC Plant Biol. 6: 20

Faria, D. A., E. M. C. Mamani, G. J. Pappas, D. GrattaPAGLIA (2011): Genotyping systems for Eucalyptus based on tetra-, penta-, and hexanucleotide repeat EST microsatellites and their use for individual fingerprinting and assignment tests. Tree Genet. Genomes 7: 63-77.

Faria, D. A., E. M. C. Mamani, M. R. PAPPas, G. J. Pappas JR. and D. GRATTAPAGLIA (2010): A selected set of ESTderived microsatellites, polymorphic and transferable across 6 species of Eucalyptus. J. Hered. 101: 512-520.

GAN, S., J. ShI, M. LI, K. WU, J. WU and J. BAI (2003): Moderate-density molecular maps of Eucalyptus urophylla S. T. Blake and E. tereticornis Smith genomes based on RAPD markers. Genetica 118: 59-67.

GuPtA, P. K. and R. K. VARShNEY (2000): The development and use of microsatellite markers for genetic analysis and plant breeding with special emphasis on bread wheat. Euphytica 113: 163-185.

Powell, W., G. C. Machray and J. Provan (1996): Polymorphisms revealed by simple sequence repeats. Trend. Plant Sci. 1: 215-222.

Rozen, S. and H. J. Skaletsky (2000): Primer3 on the WWW for general users and for biologist programmers. In: Bioinformatics methods and protocols: methods in molecular biology, eds KRAWETZ, S. and S. MiSENER. Humana Press, Totowa, NJ. 365-386.

Yonemaru, J.-I., A. Tsuyu, M. Tatsumi, K. Shigemitsu, M. TAKASHI and Y. MASAHIRO (2009): Development of genome-wide simple sequence repeat markers using whole-genome shotgun sequences of sorghum (Sorghum bicolor (L.) Moench). DNA Res. 16: 187-193.

ZHANG, X., F. Li, Y. WANG, L. XU, M. Li and S. GAN (2009): An optimized protocol for sequencing EST-PCR products in Eucalyptus. Genomics Appl. Biol. 28: 535-543.

Zhou, C., F. Li, Q. WenG, X. Yu, M. Li and S. GAN (2010): Comparison between direct sequencing and poolcloning-based sequencing of PCR products in EST-SSR marker development in Eucalyptus. Mol. Plant Breed. 8: 1 (doi:10.5376/mpb.cn.2010.08.0001). 